\title{
A reappraisal of Stegastes species occurring in the South Atlantic using morphological and molecular data
}

\author{
Allyson Santos de Souza ${ }^{*}$, Ricardo de Souza Rosa ${ }^{2}$, Rodrigo Xavier Soares ${ }^{1}$, Paulo Augusto de Lima-Filho ${ }^{3}$, \\ Claudio de Oliveira ${ }^{4}$, Oscar Akio Shibatta ${ }^{5}$ and Wagner Franco Molina ${ }^{1}$
}

\begin{abstract}
The taxonomic status of Pomacentridae species can be difficult to determine, due to the high diversity, and in some cases, poorly understood characters, such as color patterns. Although Stegastes rocasensis, endemic to the Rocas atoll and Fernando de Noronha archipelago, and S. sanctipauli, endemic to the São Pedro and São Paulo archipelago, differ in color pattern, they exhibit similar morphological characters and largely overlapping counts of fin rays and lateral-line scales. Another nominal insular species, S. trindadensis, has recently been synonymized with S. fuscus but retained as a valid subspecies by some authors. Counts and morphometric analyses and mitochondrial DNA (COI, 16SrRNA, CytB) and nuclear DNA (rag 1 and rhodopsin) comparisons of three insular species (S. rocasensis, S. sanctipauli and S. trindadensis) and three other South Atlantic species (S. fuscus, S. variabilis and S. pictus) were carried out in the present study. Analyses of the principal components obtained by traditional multivariate morphometry indicate that the species in general have similar body morphology. Molecular analyses revealed conspicuous similarity between S. rocasensis and S. sanctipauli and between S. trindadensis and S. fuscus and a clear divergence between S. variabilis from Northeast Brazil and S. variabilis from the Caribbean region. Our data suggest that S. sanctipauli is a synonym of S. rocasensis, support the synonymy of $S$. trindadensis with $S$. fuscus, and reveal the presence of a likely cryptic species in the Caribbean that has been confused historically with S. variabilis.
\end{abstract}

Keywords: Pomacentridae, Damselfish, Species delimitation, Taxonomy, Insular species

\section{Background}

Genetic analyses have revealed a large number of cryptic species in different groups of fish (e.g., $[1,2])$. The term "cryptic" species, although the definition is not unanimous, generally refers to two or more distinct species that are nominally classified as one due to the difficultto-distinguish morphologies [3]. Morphological variations with no genetic differences have been explained as phenotypic plasticity, recent isolation, incomplete limits between species, or the product of selection [4]. On the other hand, so-called polytypic species, in which genetically similar individuals of one species display

*Correspondence: souzaas@yahoo.com.br

1 Departamento de Biologia Celular e Genética, Centro de Biociências, Universidade Federal do Rio Grande do Norte, Natal, RN 59078-970, Brazil Full list of author information is available at the end of the article conspicuously different coloration or morphology, occur more frequently $[4,5]$.

Inconsistencies between color patterns with morphology and genetic markers are relatively common and have been reported for a number of fish families including Pomacentridae [6-8]. This family, whose members are known as damselfishes, is one of the most represented marine groups in reef environments [9]. Indeed, damselfishes are a diverse group, with 399 species [10], whose taxonomic definition is complicated by the occurrence of species complexes and marked variations in coloration patterns among individuals and geographic areas [11-14].

The western Atlantic contains Pomacentridae representatives of the genera Abudefduf (1 sp.), Microspathodon (1 sp.), Chromis (5 spp.), and Stegastes (7 spp.) [13, 15-19]. Some Stegastes species are considered endemic 
of insular environments of the South Atlantic, such as $S$. rocasensis Emery 1972, in the Rocas atoll (RA) and Fernando de Noronha archipelago (FNA), and S. sanctipauli Lubbock and Edwards 1981, exclusive to St. Paul's Rocks. The first two oceanic formations are part of an alignment of submarine volcanoes that make up the Fernando de Noronha Chain [20, 21]. More southward, in the Trindade and Martim Vaz archipelago (TI), located in the easternmost part of the submarine mountain chain called Vitoria-Trindade and Martim Vaz, $1167 \mathrm{~km}$ off the coast of Espírito Santo State, southeastern Brazil, S. trindadensis Gasparini, Moura and Sazima 1999, was described and considered endemic to TI $[20,21]$.

Extensively overlapping morphometric characters in Stegastes (including the synonyms Brachypomacentrus Bleeker and Eupomacentrus Bleeker), a morphologically conservative group [22], in addition to cytogenetic [23] and dominant marker similarities [24], reveal uncertainty regarding the taxonomic status and phylogenetic relationships of S. rocasensis, S. sanctipauli and S. trindadensis, and the last was recognized as a synonym of $S$. fuscus Cuvier 1830 by Gasparini and Floater [16], Carter and Kaufman [25] and Pinheiro et al. [26]. Based only on morphological criteria, S. rocasensis and S. sanctipauli have been considered similar to each other and to $S$. variabilis Castelnau 1855 [22, 27]. Although scarce biological information is available [14, 28,29], there is some genetic data or information on its evolutionary history [23, 30, 31]. In order to clarify the taxonomic status and relationships of these three insular species and test the current hypotheses of ancestrality [22, 27], counts comparisons of serial elements, traditional and geometric multivariate morphometric analyses, and analyses of mitochondrial (16S ribosomal RNA-16S, cytochrome oxidase subunit $1-\mathrm{COI}$, and cytochrome B-CytB) and nuclear gene sequences (nuclear recombination-activating gene 1-rag1 and rhodopsin—rhod) were performed.

\section{Methods}

\section{Specimen collection}

Individuals of Stegastes fuscus [MZUEL 8958, 22 specimens, 43.9-65.0 mm SL; coast of Rio Grande do Norte state $\left.(\mathrm{RN})-5^{\circ} 16^{\prime} \mathrm{S}, 35^{\circ} 22^{\prime} \mathrm{W}\right] ;$ S. rocasensis (MZUEL 8956, 9, 36.6-66.5 mm SL; RA- $\left.3^{\circ} 51^{\prime} \mathrm{S}, 33^{\circ} 49^{\prime} \mathrm{W}\right) ; S$. rocasensis (MZUEL 8960, 18, 42.7-78.2 mm SL; FNA$3^{\circ} 50^{\prime} \mathrm{S}, 32^{\circ} 24^{\prime} \mathrm{W}$ ); S. sanctipauli [MZUEL 8959, 18, 58.3-80.1 mm SL; São Pedro and São Paulo archipelago (SPSPA) $-0^{\circ} 55^{\prime} \mathrm{N}, 29^{\circ} 20^{\prime} \mathrm{W}$ ]; S. trindadensis [MZUEL 13908, 12; Trindade island (TI) $\left.-20^{\circ} 30^{\prime} \mathrm{S}, 29^{\circ} 19^{\prime} \mathrm{W}\right]$ and S. variabilis (MZUEL 8957, 18, 33.3-57.2 mm SL; coast of $\mathrm{RN}-5^{\circ} 16^{\prime} \mathrm{S}, 35^{\circ} 22^{\prime} \mathrm{W}$ ) were analyzed (Figs. 1, 2). Fragments of muscle tissue or fins were removed and stocked in microtubes $(1.5 \mathrm{ml})$ with absolute ethanol and stored at $-20{ }^{\circ} \mathrm{C}$. Voucher specimens were fixed in $10 \%$ formaldehyde, preserved in $70 \%$ ethanol and deposited in the Museu de Zoologia from Universidade Estadual de Londrina (MZUEL-Table 1).

\section{Counts, traditional and geometric multivariate morphometry}

Injury-free adults of the species identified as Stegastes fuscus $(\mathrm{n}=31)$; S. variabilis $(\mathrm{n}=18)$, S. rocasensis $(\mathrm{n}=5$; RA); S. rocasensis $(\mathrm{n}=18$; FNA); S. sanctipauli $(\mathrm{n}=17)$; and S. trindadensis $(\mathrm{n}=26)$ were used in morphometric analyses. Counts of branched rays in dorsal, pectoral and anal fins and lateral-line scales were obtained for all the specimens.

Multivariate morphometry based on measuring linear distances made it possible to investigate variations among species of Stegastes, compared by Principal Component Analysis (PCA) [32], using SHEAR software [33]. Sixteen measurements were taken with a digital caliper: standard length, head length, snout length, orbit diameter, greatest body depth, predorsal length, length of last dorsal-fin spine, length of longest dorsal ray, anal-fin base length, length of second anal-fin spine, length of longest anal ray, pectoral-fin length, pelvic-fin length, caudal-fin length, caudal-peduncle depth, and interorbital width.

Geometric morphometrics analyses were used to explore the variation in body shape in morphospace. Left side view photographs of the specimens were taken with an 8.1 megapixel Sony H10 camera, at a standard distance and position. Nine landmarks were digitized: (1) distal extremity of the premaxillary bone; (2) origin of dorsal fin; (3) end of dorsal fin; (4) origin of the anal fin; (5) end of the anal fin; (6) origin of the ventral fin; (7) insertion of pectoral fin; (8) posterior and (90 anterior orbit using tpsDig v2.16 software [34] and the images were ordered into a single TPS format with tpsUtil software [35]. Next, Procrustes superimposition [36], Multivariate Analysis of Variance (MANOVA) and Canonical Variables Analysis (CVA) were carried out. Deformation grids were obtained from the canonical variables that most influenced morphological variation, in order to more clearly identify vector variations between species.

\section{DNA extraction, PCR amplification and DNA sequencing}

Molecular analyses involved extracting DNA from three individuals of Stegastes fuscus, S. variabilis, S. pictus, S. sanctipauli, and S. trindadensis and six of S. rocasensis (three from Rocas atoll and three from Fernando de Noronha archipelago).

Total DNA was extracted from muscle tissue according to proteinase $\mathrm{K} /$ phenol-chloroform protocols [37] Fragments of three mitochondrial genes (16S, COI, and $\mathrm{CytB}$ ) and two nuclear genes (rag1 and rhod) from 


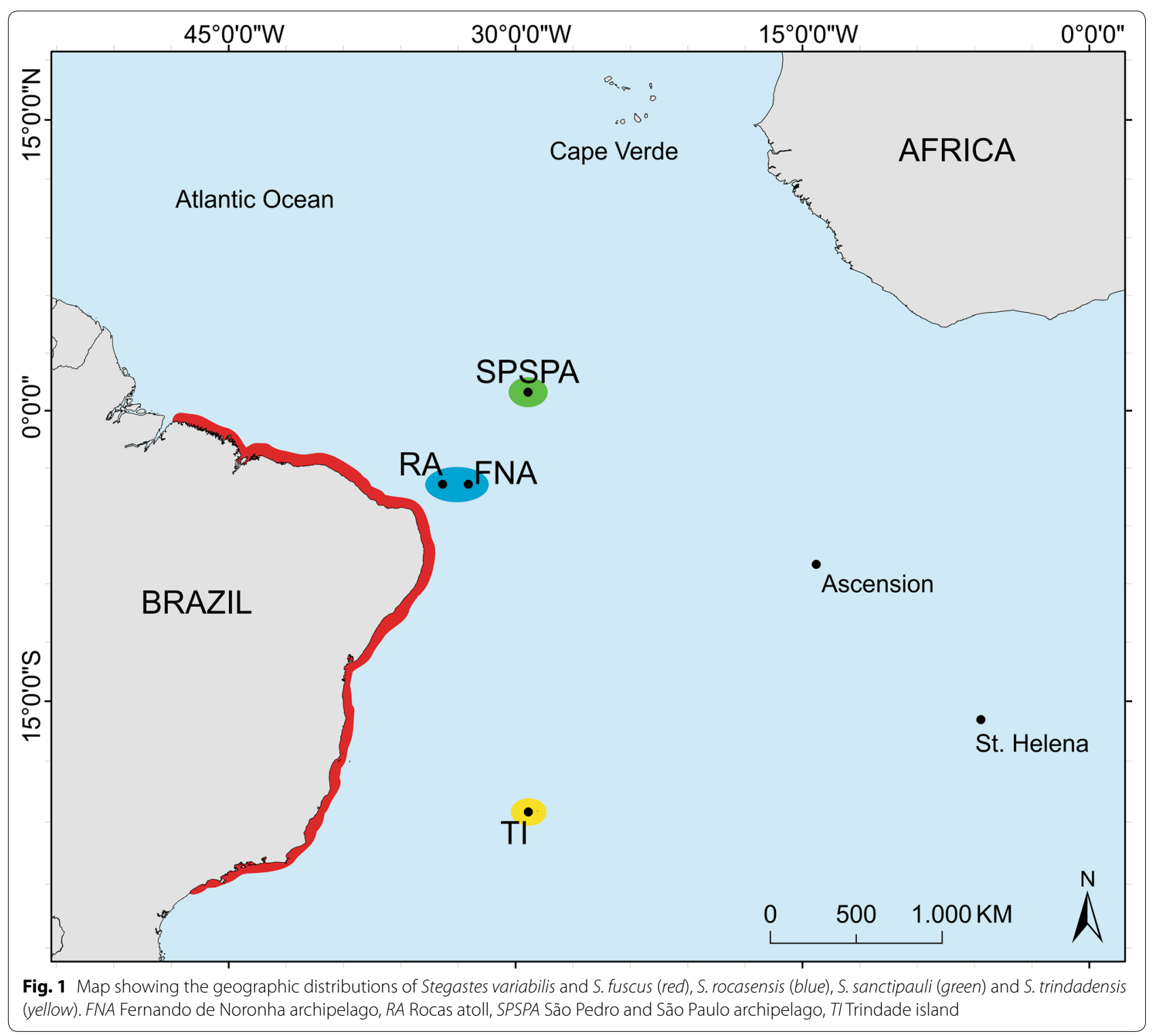

each individual were amplified using the polymerase chain reaction method (PCR). The PCRs were prepared to a final volume of $25 \mu \mathrm{l}$ containing: $1.0 \mu \mathrm{l}$ of total DNA (50 ng/ $\mu \mathrm{l}), 3.0 \mathrm{U}$ of Taq polymerase, $1.0 \mu \mathrm{l}$ of $50 \mathrm{mM} \mathrm{MgCl} 2,1.0 \mu \mathrm{l}$ of $10 \times$ buffer, $1.0 \mu \mathrm{l}$ of $10 \mathrm{mM}$ dNTP (deoxyribonucleotide triphosphate), $1.0 \mu \mathrm{l}$ of each primer $(10 \mu \mathrm{M})$, and ultrapure water to complete the final volume of the reaction. The thermal profiles for PCR were as follows: $95^{\circ} \mathrm{C}$ for $5 \mathrm{~min}$, followed by 35 cycles at $95{ }^{\circ} \mathrm{C}$ for $30 \mathrm{~s}$, annealing temperature for $45 \mathrm{~s}$ (Table 2), and $72{ }^{\circ} \mathrm{C}$ for $45 \mathrm{~s}$, with final elongation at $72{ }^{\circ} \mathrm{C}$ for $7 \mathrm{~min}$.

The PCR products $(5 \mu \mathrm{l})$ were purified with exonuclease I enzymes (3.3 U/reaction) and shrimp alkaline phosphatase (0.66 U/reaction) (GE Healthcare), in a thermal cycler, submitting the mix to a 30 -min cycle at $37^{\circ} \mathrm{C}$ and $15 \mathrm{~min}$ at $80^{\circ} \mathrm{C}$. The samples were sequenced in ACTGene Análises Moleculares Ltda. through the ABI-PRISM 3500 Genetic Analyzer automatic DNA sequencer (Applied Biosystems).

\section{Analysis of sequences}

The electroferograms obtained were verified using BioEdit software [38]. The sequences of each gene were aligned using MUSCLE [39] in the MEGA 6 software package [40]. The sequences of mitochondrial (16S, COI and $\mathrm{CytB}$ ) and nuclear genes (rag1 and rhodopsin) from each individual were concatenated, forming a single 


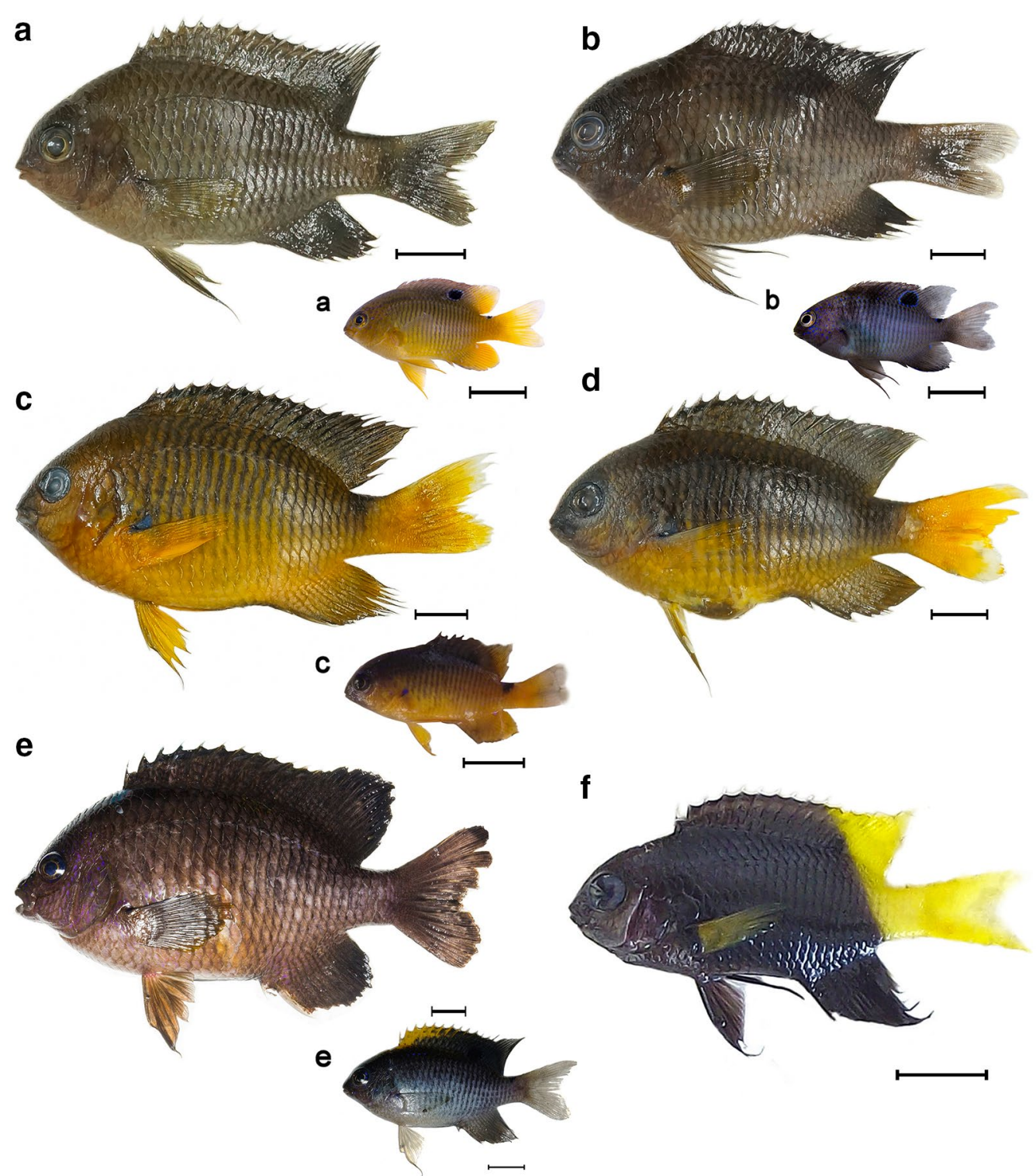

Fig. 2 Specimens of a Stegastes variabilis Castelnau 1855, b S. fuscus Cuvier 1830, c S. sanctipauli Lubbock and Edwards 1981, d S. rocasensis Emery 1972, e S. trindadensis Gasparini, Moura and Sazima 1999, f S. pictus Castelnau 1855. Figures indicated by lower case letters correspond to the juveniles of the respective species. Bars $1 \mathrm{~cm}$

nucleotide sequence. Sites with gaps were excluded from all genetic analyses.

Sequences of the COI gene of 22 additional Stegastes species or populations were obtained from BOLD (www. boldsystem.org) and used for the comparative analyses. The mean genetic divergence rates (Kimura-2-parameter model) and the neighbor-joining tree were obtained with the MEGA 6 software [40].

The relationships among insular species (S. sanctipauli, S. rocasensis and S. trindadensis) were determined by the Maximum Likelihood Method using MEGA 6 software [40]. The best evolutionary method for the sequences was determined by jModelTest2 software [41] using the Akaike information criterion. Macrodon ancylodon (Sciaenidae) and Haemulon aurolineatum (Haemulidae) were used as outgroups. These families are outgroup candidates because they, along with the Pomacentridae, are members of order Perciformes [10, 42]. The number of polymorphic sites along the sequences was estimated using DnaSP 5 software [43], while mean genetic divergence rates (p-distances) and the mean number of intra and interspecific nucleotide differences were estimated by MEGA 6 software [40]. 
Table 1 Stegastes specimens analyzed and GenBank accession numbers of mitochondrial and nuclear sequences used in phylogenetic estimates

\begin{tabular}{|c|c|c|c|c|c|c|c|c|}
\hline \multirow{2}{*}{$\begin{array}{l}\text { Taxonomic } \\
\text { identification }\end{array}$} & \multirow{2}{*}{$\begin{array}{l}\text { Collection } \\
\text { sites }\end{array}$} & \multirow[t]{2}{*}{$\mathbf{n}$} & \multirow{2}{*}{$\begin{array}{l}\text { Deposited } \\
\text { vouchers }^{\mathrm{a}}\end{array}$} & \multicolumn{5}{|c|}{ GenBank access number ${ }^{b}$} \\
\hline & & & & $16 S$ & $\mathrm{COI}$ & CytB & $\operatorname{rag} 1$ & rhod \\
\hline S. pictus & RA & 3 & MZUEL 08955 & KM077255-57 & KM077183-85 & KM077201-03 & KM077219-21 & KM077237-39 \\
\hline S. variabilis & RN & 3 & MZUEL 08957 & KM077258-60 & KM077186-88 & KM077204-06 & KM077222-24 & KM077240-42 \\
\hline S.fuscus & RN & 3 & MZUEL 08958 & KM077261-63 & KM077189-91 & KM077207-09 & KM077225-27 & KM077243-45 \\
\hline S. rocasensis & RA & 3 & MZUEL 08956 & KM077264-66 & KM077192-94 & KM077210-12 & KM077228-30 & KM077246-48 \\
\hline S. rocasensis & FNA & 3 & MZUEL 08960 & KM077267-69 & KM077195-97 & KM077213-15 & KM077231-33 & KM077249-51 \\
\hline S. sanctipauli & SPSPA & 3 & MZUEL 08959 & KM077270-72 & KM077198-200 & KM077216-18 & KM077234-36 & KM077252-54 \\
\hline S. trindadensis & $\mathrm{Tl}$ & 3 & MZUEL 13908 & KX066003-05 & KX066006-08 & KX066009-11 & KX066012-14 & KX066015-17 \\
\hline Macrodon ancylodon ${ }^{c}$ & - & 1 & - & AY253541 & JQ365417 & AY253604 & KP722921 & KP723010 \\
\hline $\begin{array}{l}\text { Haemulon aurolinea- } \\
\text { tum }^{c}\end{array}$ & - & 1 & - & JQ740958 & JQ741187 & JQ741415 & KF141251 & EF095619 \\
\hline
\end{tabular}

a Museu de Zoologia from Universidade Estadual de Londrina (MZUEL); ${ }^{\text {b }}$ sequences obtained in this study. RA Rocas atoll, RN Rio Grande do Norte state, $F N A$

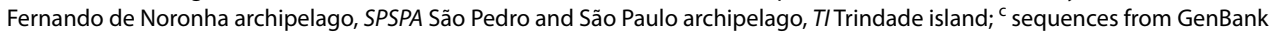

Table 2 Primers used to amplify sequences of mitochondrial and nuclear genes of Stegastes species

\begin{tabular}{|c|c|c|c|}
\hline Gene & Primers & $\operatorname{Tm}\left({ }^{\circ} \mathrm{C}\right)$ & References \\
\hline $16 S$ & $\begin{array}{l}\text { L1987 (5'-GCC TCG CCT GTT TAC CAA AAA C-3') } \\
\text { H2609 (5'-CCG GTC TGA ACT CAG ATC ACG T-3') }\end{array}$ & 52 & [65] \\
\hline $\mathrm{COI}$ & $\begin{array}{l}\text { COI-FishF2 (5'-TCG ACT AAT CAT AAA GAT ATC GGC AC-3') } \\
\text { COI-FishR2 (5'-ACT TCA GGG TGA CCG AAG AAT CAG AA-3'; }\end{array}$ & 50 & [66] \\
\hline CytB & $\begin{array}{l}\text { FishcytB-F (5'-ACC ACC GTT GTT ATT CAA CTA CAA GAA C-3') } \\
\text { CytBI-5R (5'-GGT CTT TGT AGG AGA AGT ATG GGT GGA A-3') }\end{array}$ & 52 & [67] \\
\hline rhod & $\begin{array}{l}\text { Rod-F2w (5'-AGC AAC TTC CGC TTC GGT GAG AA-3') } \\
\text { Rod-R4n (5'-GGA ACT GCT TGT TCA TGC AGA TGT AGA T-3') }\end{array}$ & 60 & [67] \\
\hline ragl & $\begin{array}{l}\text { RAG1-F3 (5'-GCC TCA GAA AAC ATG GTG CT-3') } \\
\text { RAG1-R3 (5'-CCA CAC AGG TTT CAT CTG GA-3') }\end{array}$ & 50 & [68] \\
\hline
\end{tabular}

Tm melting temperatures

\section{Results}

\section{Quantification of fin rays and lateral-line scales}

Frequency distributions of counts of fin rays and lateralline scales are presented in Table 3 . There is great similarity among species, except for $S$. pictus, which modally exhibits fewer pectoral-fin rays than the other species. Numerical differences were observed between counts taken in populations of $S$. variabilis from Brazil and those described for Caribbean region [44]. Counts do not discriminate among $S$. fuscus, S. variabilis, S. rocasensis and S. sanctipauli.

\section{Principal Component Analysis (PCA)}

The first principal component retained $88.6 \%$ of data variance, whereas in the second and third axes (sPC2 and SPC 3), it was 2.6 and $2.1 \%$, respectively (Table 4). The first PC is positively related to all measurements and was interpreted as being related to size, while the second and third, with positive and negative values, respectively, represent the shape. The individual scores for the species revealed partial overlapping among them in these components (Fig. 3). However, in the second axis, $S$. variabilis was completely separated from $S$. rocasensis, $S$. trindadensis and S. sanctipauli, but with greater similarity to $S$. fuscus, whereas $S$. fuscus presented intermediate scores between these species. The individuals identified as $S$. sanctipauli and S. rocasensis are not separated morphometrically along sPC2 and sPC3. In the third axis $S$. trindadensis is separated from $S$. rocasensis (Fig. 3). The samples identified as $S$. rocasensis from Fernando de Noronha archipelago and S. rocasensis from Rocas atoll are not separated in any of the axes, nor is the sample of S. sanctipauli.

The variables that discriminate $S$. fuscus and $S$. variabilis from S. rocasensis, S. trindadensis and S. sanctipauli by the second PC are caudal peduncle depth, interorbital width and body depth (positive loadings, Table 4). By contrast, the variables with the highest values in $S$. 
Table 3 Frequency distribution of counts for 7 species of Stegastes from the Western Atlantic

\begin{tabular}{|c|c|c|c|c|c|c|c|c|c|}
\hline \multirow[t]{2}{*}{ Species } & \multicolumn{7}{|c|}{ Dorsal rays } & \multirow[t]{2}{*}{ Variation } & \multirow[t]{2}{*}{ Mean } \\
\hline & $\mathbf{N}$ & 12 & 13 & 14 & 15 & 16 & 17 & & \\
\hline S. sanctipauli* & 21 & - & - & 1 & 20 & - & - & $14-15$ & 14.9 \\
\hline S. sanctipauli & 11 & - & - & 1 & 10 & - & - & $14-15$ & 14.9 \\
\hline S. rocasensis* & 36 & - & 1 & 3 & 31 & 1 & - & $13-16$ & 14.9 \\
\hline S. rocasensis (RA) & 9 & - & - & 2 & 6 & 1 & - & $14-16$ & 14.8 \\
\hline S. fuscus & 18 & - & - & 2 & 15 & 1 & - & $15-16$ & 14.9 \\
\hline S. variabilis* & 57 & - & - & 3 & 23 & 29 & 2 & $14-17$ & 15.5 \\
\hline S. variabilis & 10 & - & - & 4 & 6 & - & - & $14-15$ & 14.6 \\
\hline S. pictus & 13 & - & - & - & 7 & 6 & - & $15-16$ & 15.5 \\
\hline S. trindadensis* & 23 & - & - & $x$ & $x$ & $x$ & $x$ & $14-17$ & $x$ \\
\hline S. trindadensis & 12 & - & - & - & - & - & 12 & 17 & 17 \\
\hline \multirow[t]{2}{*}{ Species } & \multicolumn{7}{|c|}{ Anal rays } & \multirow[t]{2}{*}{ Variation } & \multirow[t]{2}{*}{ Mean } \\
\hline & $N$ & 11 & 12 & 13 & 14 & 15 & 16 & & \\
\hline S. sanctipauli* & 21 & - & - & 21 & - & - & - & 13 & 13.0 \\
\hline S. sanctipauli & 11 & - & - & 9 & 2 & - & - & $13-14$ & 13.2 \\
\hline S. rocasensis* & 36 & - & - & 36 & - & - & - & 13 & 13.0 \\
\hline S. rocasensis (RA) & 9 & - & - & 7 & 2 & - & - & $13-14$ & 13.2 \\
\hline S. fuscus & 18 & - & 3 & 9 & 6 & - & - & $12-14$ & 13.2 \\
\hline S. variabilis* & 57 & - & 1 & 20 & 32 & 4 & - & $12-15$ & 13.7 \\
\hline S. variabilis & 10 & - & 3 & 7 & - & - & - & $12-13$ & 12.7 \\
\hline S. pictus & 13 & - & 1 & 4 & 7 & 1 & - & $12-15$ & 13.6 \\
\hline S. trindadensis* & 23 & - & - & $x$ & $x$ & $x$ & - & $13-15$ & $x$ \\
\hline S. trindadensis & 12 & - & - & 1 & 7 & 4 & - & $13-15$ & 14.2 \\
\hline \multirow[t]{2}{*}{ Species } & \multicolumn{7}{|c|}{ Pectoral rays } & \multirow[t]{2}{*}{ Variation } & \multirow[t]{2}{*}{ Mean } \\
\hline & $N$ & 17 & 18 & 19 & 20 & 21 & 22 & & \\
\hline S. sanctipauli* & 21 & - & - & 2 & 18 & 1 & - & $19-21$ & 19.9 \\
\hline S. sanctipauli & 11 & - & - & 1 & 10 & - & - & $19-20$ & 19.9 \\
\hline S. rocasensis* & 36 & - & - & 2 & 31 & 3 & - & $19-21$ & 20.0 \\
\hline S. rocasensis (RA) & 9 & - & - & 1 & 8 & - & - & $19-20$ & 19.9 \\
\hline S. fuscus & 18 & - & - & 2 & 8 & 8 & - & $19-21$ & 20.3 \\
\hline S. variabilis* & 57 & - & 1 & 16 & 38 & 2 & - & $18-21$ & 19.7 \\
\hline S. variabilis & 10 & - & - & 1 & 7 & 2 & - & $19-21$ & 20.1 \\
\hline S. pictus & 13 & 1 & 11 & 1 & - & - & - & $17-19$ & 18.0 \\
\hline S. trindadensis* & - & - & - & $x$ & $x$ & $x$ & - & $19-21$ & $x$ \\
\hline S. trindadensis & 12 & - & 1 & 11 & - & - & - & $18-19$ & 18.9 \\
\hline \multirow[t]{2}{*}{ Species } & \multicolumn{7}{|c|}{ Lateral line-scales } & \multirow[t]{2}{*}{ Variation } & \multirow[t]{2}{*}{ Mean } \\
\hline & $\mathrm{N}$ & 16 & 17 & 18 & 19 & 20 & 21 & & \\
\hline S. sanctipauli* & 12 & - & - & - & 2 & 19 & - & $19-20$ & 19.8 \\
\hline S. sanctipauli & 11 & - & - & - & - & 11 & - & 20 & 20.0 \\
\hline S. rocasensis* & 36 & - & - & 2 & 4 & 29 & 1 & $18-21$ & 19.8 \\
\hline S. rocasensis (RA) & 9 & - & - & - & 2 & 7 & - & $19-20$ & 19.8 \\
\hline S. fuscus & 18 & - & - & - & - & 15 & 3 & $20-21$ & 20.2 \\
\hline S. variabilis* & 57 & - & - & 2 & 28 & 27 & - & $18-20$ & 19.4 \\
\hline S. variabilis & 10 & - & - & - & 1 & 9 & - & $19-20$ & 19.9 \\
\hline S. pictus & 13 & - & - & - & 1 & 12 & - & $19-20$ & 19.9 \\
\hline
\end{tabular}


Table 3 continued

\begin{tabular}{llllllllll}
\hline Species & \multicolumn{3}{l}{ Lateral line-scales } & \multicolumn{1}{c}{} & & Variation & Mean \\
\cline { 2 - 8 } & $\mathbf{N}$ & $\mathbf{1 6}$ & $\mathbf{1 7}$ & $\mathbf{1 8}$ & $\mathbf{1 9}$ & $\mathbf{2 0}$ & $\mathbf{2 1}$ & \\
\hline S. trindadensis* & 23 & - & - & - & $\times$ & $\times$ & $\times$ & $19-21$ \\
S. trindadensis & 12 & - & - & - & 1 & 10 & 1 & $19-21$ & 20.0 \\
\hline
\end{tabular}

Literature data for S. variabilis and S. pictus [44], S. rocasensis [22], S. sanctipauli [27] and S. trindadensis [17] are highlighted with an asterisk RA Rocas atoll

Table 4 Variable loadings from sheared principal components analysis for morphometric characters of Stegastes species

\begin{tabular}{llrr}
\hline & \multicolumn{3}{l}{ Principal component } \\
\cline { 2 - 4 } & PC1 & sPC2 & \multicolumn{1}{c}{ sPC3 } \\
\hline Percentage of variance & 88.63 & 2.640 & 2.118 \\
Variables & & & \\
Standard length & 0.258112 & -0.001448 & -0.210450 \\
Head length & 0.241320 & 0.047276 & -0.232662 \\
Snout length & 0.303126 & -0.296250 & -0.552961 \\
Orbit diameter & 0.200732 & -0.020172 & -0.235335 \\
Greatest body depth & 0.255074 & 0.319120 & -0.100978 \\
Predorsal length & 0.246296 & 0.030081 & -0.044675 \\
Length of last dorsal spine & 0.240925 & 0.016873 & 0.384464 \\
Length of longest dorsal ray & 0.276920 & -0.264052 & 0.202150 \\
Anal fin base length & 0.237181 & 0.094722 & 0.219734 \\
Length of second anal spine & 0.245731 & -0.383452 & 0.149272 \\
Length of longest anal ray & 0.261460 & -0.477297 & 0.144833 \\
Pectoral fin length & 0.241844 & 0.114243 & 0.014072 \\
Pelvic fin length & 0.201796 & 0.123833 & 0.466247 \\
Caudal fin length & 0.271083 & -0.167673 & -0.092469 \\
Caudal peduncle depth & 0.241178 & 0.406146 & 0.017068 \\
Interorbital width & 0.258160 & 0.360734 & -0.140756 \\
\hline
\end{tabular}

rocasensis, S. trindadensis and S. sanctipauli are length of the longest anal ray, length of the second anal spine, snout length, and length of the longest dorsal ray (negative loadings in Table 4). Stegastes trindadensis differs from both populations of $S$. rocasensis by having a longer pelvic fin, last dorsal spine, anal-fin base, and longest dorsal ray (positive loadings, Table 4), and shorter snout, smaller orbit diameter, and shorter head (negative values, Table 4).

\section{Geometric morphometric analysis}

Canonical variables 1 and 2 contributed more to the shape variation among samples of Stegastes (Procrustes MANOVA: $\mathrm{SS}=0.086 ; \mathrm{df}=70 ; \mathrm{F}=11.93 ; p<0.001$; Pillai's trace $=2.37$; Pillai's trace $p<0.001$ ), accounting for $83.7 \%(C V 1=57.3$; $C V 2=26.4 ; \mathrm{p}<0.001)$. The

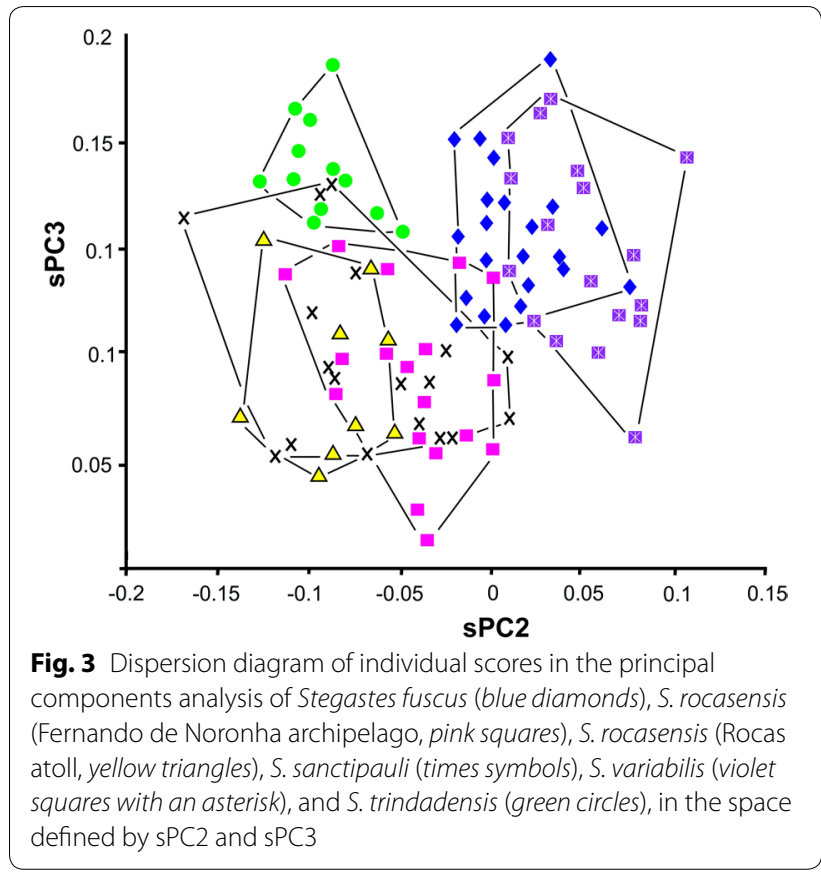

individual scores of the species demonstrate a marked overlap in the morphospace of S. fuscus and S. variabilis along the two axes. Stegastes sanctipauli individuals overlapped with those of S. rocasensis (RA; FNA) (Fig. 4). Stegastes rocasensis individuals of RA and FNA were more discriminated between each other than with the sample of SPSPA. The deformation grids obtained from CV2 show morphological distinctions between S. fuscus and S. variabilis relative to landmarks $1-3$ and 6-9, which are related to the position of the fins (anal, dorsal, pelvic and pectoral), mouth and eyes (Fig. 4a). The warped outlines generated from CV1 data demonstrate the morphological diversification of $S$. rocasensis and S. sanctipauli in relation to the position of landmarks 2-7 (Fig. 4b), which correspond primarily to variations in anterior and posterior body height. Body variations between S. fuscus and S. trindadensis show differences in pectoral- and anal-fin position, as well as body length and height (Fig. 4c). 


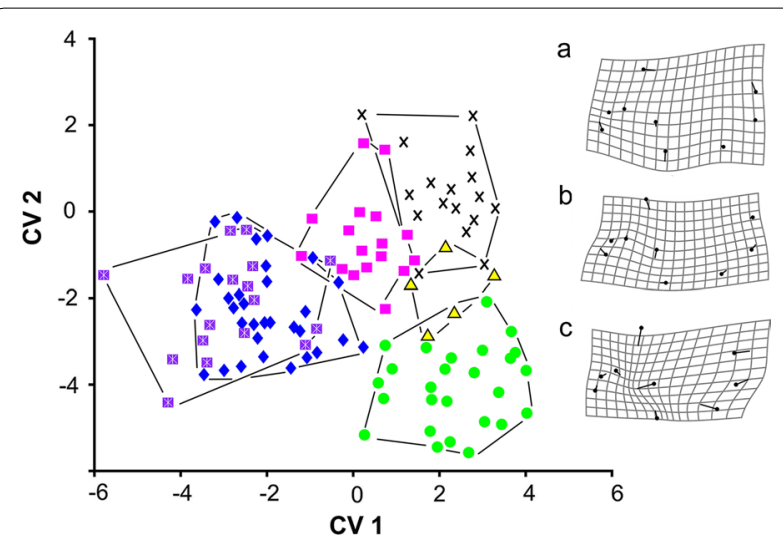

Fig. 4 Analysis of the canonical variables of body shape data of Stegastes fuscus (blue diamonds), S. rocasensis (Fernando de Noronha archipelago, pink squares), S. rocasensis (Rocas atoll, yellow triangles), S. sanctipauli (times symbo/s), S. trindadensis (green circles) and S. variabilis (violet squares with an asterisk), between the CV1 and CV2 axes $(C V 1=57.3 \%$ and $C V 2=26.4 \%)$. The deformation grids illustrate the variation in body shape of a Stegastes fuscus and S. variabilis, $\mathbf{b} \mathrm{S}$. rocasensis and S. sanctipauli, and $\mathbf{c}$ S. fuscus and S. trindadensis on CV1

\section{Genetic variation}

For genetic diversity analyses 90 nucleotide sequences were generated, 18 for each of the five molecular markers analyzed. The access numbers of sequences in GenBank are listed in Table 1. After the alignments the sequences resulted in 540 base pairs (bp) of gene 16S, 668 bp of CytB, 633 bp of COI, 290 bp of rag1 and 449 bp of rhodopsin. The concatenation of five fragments resulted in consensus sequences of $2580 \mathrm{bp}$, which were used in genetic comparisons.

Stegastes sanctipauli (SPSPA) and S. rocasensis (FNA/ RA) specimens shared identical haplotypes for all the genes, except for one specimen of $S$. rocasensis from the FNA, which exhibited a mutation $(t s \mathrm{G} \rightarrow \mathrm{A})$ in the
CytB gene. Stegastes variabilis showed more genetic differences in relation to $S$. rocasensis, $S$. sanctipauli and $S$. trindadensis than to the coastal species S. fuscus. The mean number of intraspecific nucleotide differences ranged from 0 to 2 (Table 5). The nucleotide diversity of concatenated sequences was extremely low in $S$. rocasensis from FNA and RA, and absent in $S$. sanctipauli and $S$. rocasensis from RA $(0 \pm 0.0)$. The highest mean nucleotide differences in the species under study was found between $S$. pictus and $S$. variabilis $(228 \pm 13)$.

\section{Comparative genetic analyses}

A neighbor-joining analysis of the COI sequences with 27 species/populations shows that the genetic distance among species ranges from $0.000 \pm 0.000$ to $0.207 \pm 0.021$ (Additional file 1: Table S1). Genetic distance values of $0.000 \pm 0.000$ were observed between Stegastes rocasensis from literature and present study, between $S$. rocasensis and $S$. sanctipauli, and between S. pictus from literature and present study. A genetic distance of $0.001 \pm 0.001$ was observed between $S$. trindadensis and a sample of S. fuscus analyzed in the present study. Between S. variabilis and a sample of $S$. fuscus analyzed in the present study a genetic distance of $0.040 \pm 0.008$ was observed. The relationship among samples is showed in the Fig. 5.

Maximum likelihood using the concatenated sequences of 16S, COI, CytB, rag1 and rhod genes produced resolved clusters with high bootstrap values that clarify the relationships among Atlantic species of Stegastes (Fig. 6). In both analyses (COI and concatenated sequences) the data clearly demonstrate a clade formed by $S$. rocasensis (RA and FNA) and $S$. sanctipauli, whose individuals are genetically the same, as well as almost complete genetic similarity between S. fuscus and S. trindadensis. Stegastes variabilis and S. pictus show a low genetic similarity with insular forms.

Table 5 Mean pairwise distances (p-distance) (lower diagonal) and mean number of intraspecific (in parentheses) and interspecific (upper diagonal) nucleotide differences with their respective standard errors based on partial sequences of $16 \mathrm{~S}, \mathrm{COI}, \mathrm{CytB}$, rag 1 and rhodopsin genes ( $2580 \mathrm{bp}$ )

\begin{tabular}{|c|c|c|c|c|c|c|c|}
\hline Species & $\begin{array}{l}1 . \\
(0.6 \pm 0.6)\end{array}$ & $\begin{array}{l}2 . \\
(2 \pm 1.1)\end{array}$ & $\begin{array}{l}3 . \\
(1.3 \pm 0.9)\end{array}$ & $\begin{array}{l}4 . \\
(0 \pm 0.0)\end{array}$ & $\begin{array}{l}5 . \\
(0.6 \pm 0.6)\end{array}$ & $\begin{array}{l}6 . \\
(0.0 \pm 0.0)\end{array}$ & $\begin{array}{l}7 . \\
(0.0 \pm 0.0)\end{array}$ \\
\hline 1. S. pictus & - & $213 \pm 13$ & $206 \pm 12$ & $204 \pm 12$ & $204 \pm 12$ & $204 \pm 12$ & $206 \pm 12$ \\
\hline 2. S. variabilis & $0.087 \pm 0.005$ & - & $202 \pm 13$ & $214 \pm 13$ & $214 \pm 13$ & $214 \pm 13$ & $201 \pm 13$ \\
\hline 3. S. fuscus & $0.084 \pm 0.004$ & $0.083 \pm 0.005$ & - & $88 \pm 8.0$ & $89 \pm 8.0$ & $88 \pm 8.0$ & $3.6 \pm 1.8$ \\
\hline 4. S. rocasensis RA & $0.084 \pm 0.005$ & $0.088 \pm 0.005$ & $0.036 \pm 0.004$ & - & $0.3 \pm 0.3$ & $0.0 \pm 0.0$ & $87 \pm 8.0$ \\
\hline 5. S. rocasensis FNA & $0.084 \pm 0.005$ & $0.088 \pm 0.005$ & $0.036 \pm 0.004$ & $0.000 \pm 0.000$ & - & $0.3 \pm 0.3$ & $87 \pm 8.0$ \\
\hline 6. S. sanctipauli & $0.084 \pm 0.005$ & $0.088 \pm 0.005$ & $0.036 \pm 0.004$ & $0.000 \pm 0.000$ & $0.000 \pm 0.000$ & - & $87 \pm 8.0$ \\
\hline 7. S. trindadensis & $0.084 \pm 0.004$ & $0.088 \pm 0.005$ & $0.001 \pm 0.004$ & $0.035 \pm 0.003$ & $0.035 \pm 0.003$ & $0.035 \pm 0.003$ & - \\
\hline
\end{tabular}

Analysis based on 1000 bootstrap replications; gaps were considered a pairwise deletion 


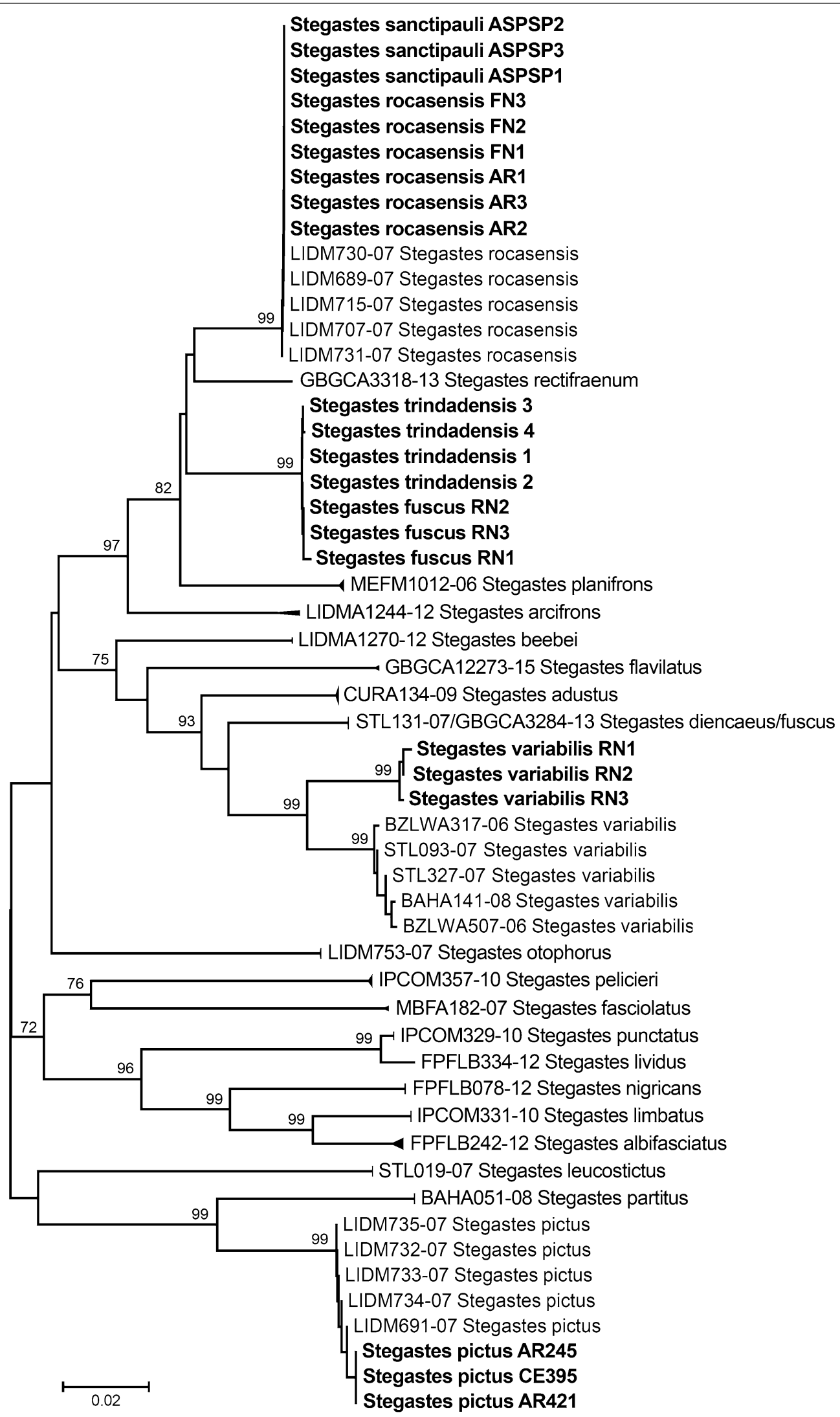


(See figure on previous page.)

Fig. 5 Neighbor-joining tree derived from COl sequences of Stegastes. Analysis based on the Kimura-2-parameter evolutionary model with 1000 bootstrap replicates (only values higher than 70 shown); SPSPA São Pedro and São Paulo archipelago, RA Rocas atoll, FNA Fernando de Noronha archipelago, TITrindade island; numbers below branches indicate bootstrap percentages; numbers before species names refer to BOLD sequences; The COl sequences obtained in this study are highlighted

\section{Discussion}

Morphological approaches, associated with mitochondrial- and nuclear-gene analyses between continental and insular species of Stegastes in the western Atlantic displayed putative incongruities with respect to the taxonomic status attributed to the insular species $S$. rocasensis, S. sanctipauli, and S. trindadensis.

Classification of Stegastes species is particularly dependent on color patterns, given that they exhibit conservative morphology [12]. Indeed, discrimination of some species through the exclusive use of phenotypic criteria has been problematic [45], since it reveals limited or ambiguous morphological characters or those with significant plasticity. Furthermore, phenotypic variations are not always effective phylogenetic characters, given that they may reflect adaptations to different ecological regimes to which the species are subjected in their distribution area [46].

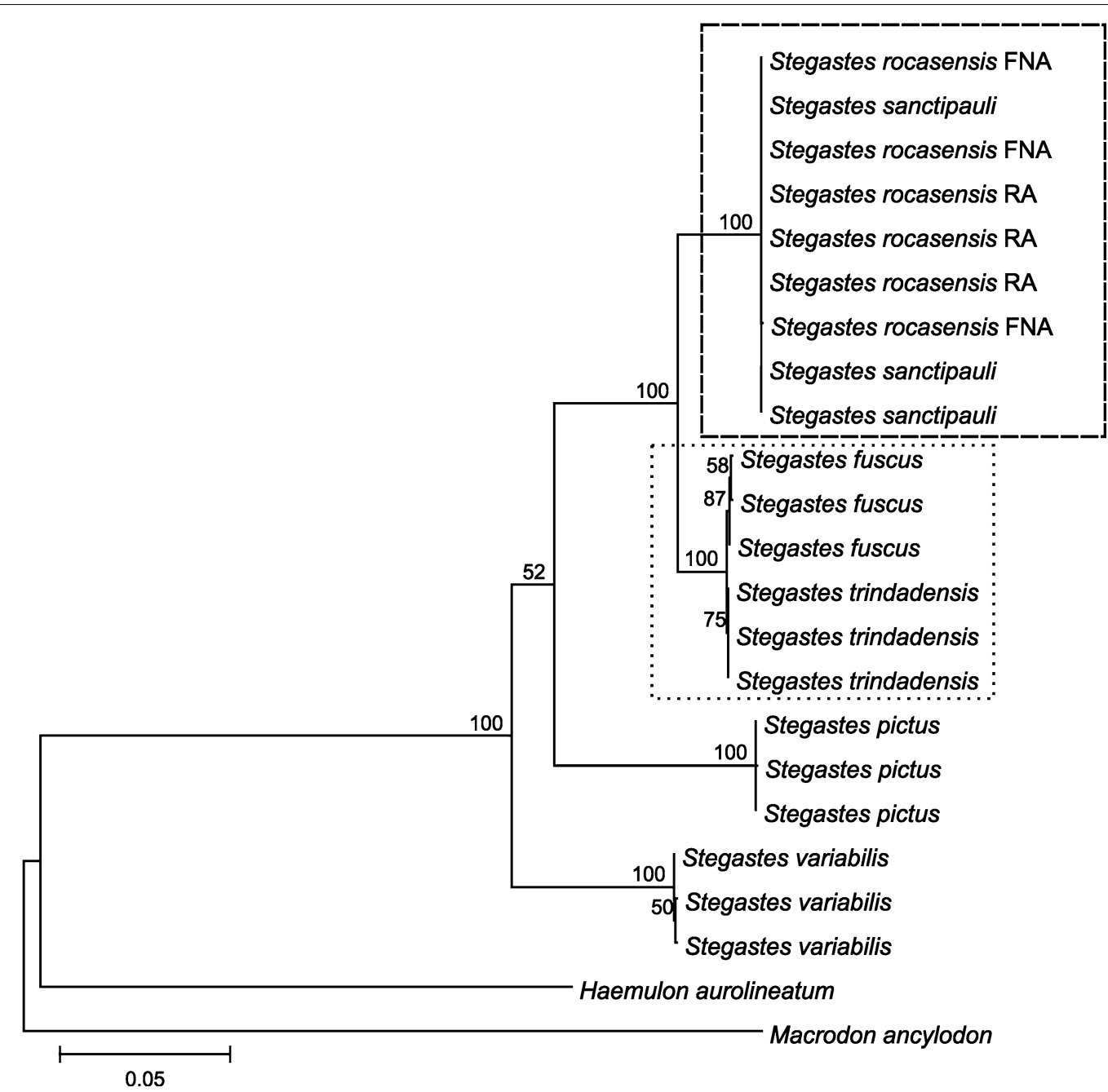

Fig. 6 Maximum likelihood tree based on the combination of 16S, COI, CytB, rag1 and rhod (2580 pb) sequences of Stegastes. Analysis based on the GTR + G evolutionary model with 1000 bootstrap replicates. Highlighted are the close relationships between the insular species S. rocasensis and S. sanctipauli and between S. fuscus and S. trindadensis. SPSPA São Pedro and São Paulo archipelago, RA Rocas atoll, FNA Fernando de Noronha archipelago, TITrindade island. Numbers below branches indicate maximum likelihood bootstrap percentages 
Aspects of coloration have masked the marked morphological similarities between Stegastes rocasensis and $S$. sanctipauli as observed in the present study. The juveniles and adults of the former are notably bicolored (blue dorsally and yellow ventrally), exhibiting dark lines on the side of the body in large individuals. Stegastes sanctipauli exhibits bright yellow to dark green or yellowish-brown coloration in adults, whereas juveniles have yellow heads and bodies, darkening slightly on the dorsal portion. Dark lines are observed on the flanks below the lateral line. The presence of a body with yellow color patterns is also shared with $S$. variabilis. On the other hand, juvenile Stegastes fuscus exhibits bright-blue coloration on the dorsum, becoming lighter ventrally, and adults are largely brown. Stegastes trindadensis displays similar coloration to that of the continental species S. fuscus, from which it is distinguished in the juvenile phase by the yellow coloration of the beginning of the dorsal fin [14].

In the Fernando de Noronha archipelago, Rocas atoll and São Pedro and São Paulo archipelago, the abundance of $S$. rocasensis and $S$. sanctipauli individuals is directly related to the structural composition of the environment and diversity of the substrate cover [47]. In this respect, these insular regions can mobilize phenotypic responses adaptive to different selective pressures, both in terms of body shape and coloration of individuals from each region. Abnormal body coloration has been described in individual species of Stegastes [48, 49], including four of those analyzed here: $S$. fuscus, S. variabilis, S. rocasensis and S. pictus $[14,15,50]$. These variations can be due to non-genetic factors [14], or even, in this or other genera, intrapopulational characteristics, without being necessarily supported, however, by very high levels of genetic differentiation [51].

Menezes and Figueiredo [52] underscored the greater similarity in coloration and morphological characters between S. fuscus, S. rocasensis and S. sanctipauli, compared to other species of Stegastes on the Brazilian coast. Indeed, the modal values of counts in the three species are largely concordant, with marked overlapping of minimum and maximum values. However, this did not occur with S. pictus, which show a lower value for pectoral rays (18).

Analyses of the principal components obtained by traditional multivariate morphometry indicated that the species in general have similar body morphology. In relation to insular forms, $S$. rocasensis from RA and FNA exhibit overlapping morphological aspects. These two populations of $S$. rocasensis demonstrated markedly similar morphology to that of $S$. sanctipauli, and accurate ordering on the sPC2 and sPC 3 axes. In fact, both species display morphological patterns more similar to each other than to the other species of Stegastes analyzed.
On the other hand, the continental species $S$. variabilis exhibits only partial discrimination of insular individuals, which could suggest the effect of different environmental pressures.

Although morphological diversification occurs between Stegastes species, they share conservative body patterns. Similarly to multivariate analyses, geometric morphometry analyses also show significant morphological similarity between S. rocasensis (FNA) and S. sanctipauli. Curiously, subtle body differences were more common between $S$. rocasensis individuals from RA and FNA, than with S. sanctipauli. This may be caused by distinct environmental factors, causing a disruptive selection of morphotypes adapted to local conditions. Indeed, as a response to environmental characteristics, many fish species demonstrate considerable phenotypic plasticity that increases their aptitude to a determinate environment [53]. When compared to other insular ecosystems, the low habitat diversity of Rocas atoll [54] may have driven the morphological changes observed in the population of $S$. rocasensis from RA due to the different ecological resources in the systems $[46,55,56]$.

Variations in body shape between the species of Stegastes analyzed were significant in terms of the positions of the dorsal and anal fins, and body height. These ecomorphological divergences suggest adaptations related to the swimming process, with direct implications on habitat use [57], biotic interactions [58] and foraging [59]. On the other hand, morphological changes in position and mouth size could reflect different degrees of food specialization, especially in relation to the type and potential size of the prey [60]. The phenotypic plasticity identified in populations of $S$. rocasensis from RA, FNA and SPSPA indicate an intense environmental effect on the local adaptive patterns of each population. Indeed, in the damselfish Abudefduf saxatilis, counts and multivariate morphometry analyses between different populations, revealed clinal variation between northeastern/ RA-SPSPA regions and the southern coast of Brazil, in addition to marked morphological differences between the populations of Rocas atoll, Fernando de Noronha archipelago and São Pedro and São Paulo archipelago [61]. This condition has been identified in other Atlantic species, such as the frillfin goby (Bathygobius soporator), which exhibits significant morphological variations between contiguous populations along the Brazilian coast, the action of ecological factors being the likely mobilizers of morphological diversification [46].

In groups with marked phenotypic plasticity, such as Pomacentridae, genetic analyses are particularly revealing regarding population structuring [51], or defining the biological status of groups whose morphological characteristics have not been resolved. Analyses of 16S, 
COI, CytB, rag1 and rhod gene sequences, widely used in phylogenetic evaluation, enabled the assessment of taxonomic status and the level of genetic divergence between the insular forms $S$. rocasensis, S. sanctipauli and S. trindadensis in relation to other congeneric species. In this respect, despite the various sequences used, $S$. rocasensis and $S$. sanctipauli showed no genetic divergence between them, suggesting that they represent a single species. Similarly, a very low genetic divergence was identified between S. fuscus and S. trindadensis (0.1\%). Our genetic data support the synonymy of $S$. trindadensis with $S$. fuscus and do not support subspecific division within that species.

Analyses with the COI sequences of Stegastes species confirm that samples of $S$. rocasensis (our data and also data from the literature) and S. sanctipauli are genetically identical. The genetic distance between our samples of S. trindadensis and S. fuscus also show that they are almost identical. A single record in the BOLD database identified as S. fuscus does not match our sequences of $S$. fuscus but matches sequences of $S$. diencaeus and appears to be a misidentification. A comparison between our data for S. pictus and the BOLD data shows no difference between them. On the other hand, a comparison of our COI data of samples of S. variabilis from northeast Brazil with sequences of S. variabilis from the Caribbean area showed a genetic distance between them of $\mathrm{d}=0.040 \pm 0.008$. Barcoding studies with fishes showed that the genetic distance (based on the Kimura-2-parameter model) between species usually is around $2 \%$ [62]; thus, the present data on $S$. variabilis suggest the possible occurrence of a cryptic species. Although counts of more Brazilian specimens of $S$. variabilis are needed, Table 3 indicates that there may be modal differences in some counts between Brazilian and Caribbean populations.

Stegastes sanctipauli was described as endemic to SPSPA, an insular region approximately $600 \mathrm{~km}$ from FNA and $700 \mathrm{~km}$ from RA, an occurrence site of $S$. rocasensis. The occurrence of $S$. rocasensis in the remote SPSPA [63] can indicate color polymorphisms or evidence of sporadic recruitment between these two areas. Nevertheless, it demonstrates a more geographically or morphologically diffuse situation than was previously believed. Thus, the evidence that $S$. rocasensis and $S$. sanctipauli are the same species suggests the occurrence of color polymorphism maintained by different selective pressures between these insular regions. Recent evidence of phylogeographic patterns in the Brown Chromis (Chromis multilineata) demonstrates gene flow, involving FNA and SPSPA [51]. Despite the suggestion of greater isolation in the SPSPA population, also identified for $S$. sanctipauli [24], the population of this species exhibits moderate genetic structuring between the insular regions and other coastal populations. Our morphological and genetic data show that the physical distance between the sites of $S$. rocasensis and $S$. sanctipauli apparently do not preclude gene flow between these occurrence areas.

\section{Conclusion}

It cannot be ruled out that $S$. rocasensis, $S$. sanctipauli and $S$. fuscus from Trindade Island (S. trindadensis) may represent species in statu nascendi [64], where reproductive isolation remains incomplete, but the absence of genetic differentiation and distinct morphological characters between S. rocasensis and S. sanctipauli and between S. trindadensis and S. fuscus is strong evidence for the recognition of two versus four species. On the other hand, the differentiation observed between Brazilian and Caribbean S. variabilis is strong evidence of a putative new species.

\section{Additional file}

Additional file 1: Table S1. Genetic divergence (Kimura-2-parameter) among Stegastes species (lower diagonal) with their respective standard errors (upper diagonal) based on partial sequences of COI (658 bps).

\section{Abbreviations \\ RA: Rocas atoll; FNA: Fernando de Noronha archipelago; SPSPA: São Pedro and São Paulo archipelago; TI: Trindade and Martim Vaz archipelago; 16S: $16 \mathrm{~S}$ ribosomal RNA; COI: cytochrome oxidase subunit 1; CytB: cytochrome B; Rag 1: nuclear recombination-activating gene 1; Rhod: rhodopsin; MZUEL: Museu de Zoologia from Universidade Estadual de Londrina; PCA: Principal Component Analysis; MANOVA: Multivariate Analysis of Variance; CVA: Canonical Variables Analysis; PCR: polymerase chain reaction.}

\section{Authors' contributions}

ASS, RSR, and WFM conceived the study. ASS and RXS collected the specimens. ASS, CO and WFM carried out the molecular genetic analyses. RSR and OAS carried out the counts and the specimens identification. OAS, PAL-F, RXS and WFM carried out the morphometric analyses. ASS and WFM wrote the manuscript, with significant input of all coauthors. All authors read and approved the final manuscript.

\section{Author details}

${ }^{1}$ Departamento de Biologia Celular e Genética, Centro de Biociências, Universidade Federal do Rio Grande do Norte, Natal, RN 59078-970, Brazil. ${ }^{2}$ Departamento de Sistemática e Ecologia, CCEN, Universidade Federal da Paraíba, Campus I, João Pessoa, PB 58051-900, Brazil. ${ }^{3}$ Instituto Federal de Educação, Ciência e Tecnologia do Rio Grande do Norte, Santa Cruz, RN, Brazil. ${ }^{4}$ Departamento de Morfologia, Instituto de Biociências, Universidade Estadual Paulista (UNESP), Campus de Botucatu, Botucatu, SP 18618-970, Brazil. ${ }^{5}$ Departamento de Biologia Animal e Vegetal, Centro de Biociências, Universidade Estadual de Londrina, Londrina, PR 86057-970, Brazil.

\section{Acknowledgements}

The authors thank the National Counsel of Technological and Scientific Development (Conselho Nacional de Desenvolvimento Científico e Tecnológico) (CNPq-Proc. 141234/2009-1; 309879/2013-2; 442664/2015-0) for financial support, and for the research scholarship awarded to ASS and RXS, and Instituto Chico Mendes de Conservação da Biodiversidade for the specimen collection license (\#19135-5)

\section{Competing interests}

The authors declare that they have no competing interests. 


\section{Availability of data and material}

Immediate.

\section{Consent for publication}

All the authors approved the paper for publication in this journal.

\section{Ethics approval and consent to participate}

The experimental work fulfills all ethical 331 guidelines regarding the handling of specimens. The collection and handling of specimens followed protocols approved by the Ethics Committee on the Use of Animals of the Federal University of Rio Grande do Norte (Process 044/2015). All the authors consent in participate and are in agreement with the article content.

Received: 5 June 2016 Accepted: 22 September 2016

Published online: 13 December 2016

\section{References}

1. Griffiths AM, Sims DW, Cotterell SP, El Nagar A, Ellis JR, Lynghammar A, McHugh M, Neat FC, Pade NG, Queiroz N, Serra-Pereira B, Rapp T, Wearmouth VJ, Genner MJ. Molecular markers reveal spatially segregated cryptic species in a critically endangered fish, the common skate (Dipturus batis). Proc Biol Sci. 2010;277:1497-503.

2. DiBattista JD, Wilcox C, Craig MT, Rocha LA, Bowen BW. Phylogeography of the Pacific Blueline Surgeonfish, Acanthurus nigroris, reveals high genetic connectivity and a cryptic endemic species in the Hawaiian Archipelago. J Mar Biol. 2011. doi:10.1155/2011/839134

3. Bickford D, Lohman DJ, Sodhi NS, Ng PK, Meier R, Winker K, Ingram K, Das I. Cryptic species as a window on diversity and conservation. Trends Ecol Evol. 2007:22:148-55.

4. Schultz JK, Pyle RL, Demartini E, Bowen BW. Genetic connectivity among color morphs and Pacific archipelagos for the flame angelfish, Centropyge loriculus. Mar Biol. 2007;151:167-75.

5. Souza AS, Dias-Júnior EA, Machado EG, Galetti PM Jr, Pichorim M, Molina WF. Wide-range genetic connectivity of coney, Cephalopholis fulva (Epinephelidae), through oceanic islands and continental Brazilian coast. An Acad Bras Ciênc. 2015;87:121-36.

6. Planes S, Doherty PJ. Genetic relationships of the colour morphs of Acanthochromis polyacanthus (Pomacentridae) on the northern Great Barrier Reef. Mar Biol. 1997;130:109-17.

7. Bernardi G, Holbrook SJ, Schmitt RJ, Crane NL, DeMartini E. Species boundaries, populations and colour morphs in the coral reef threespot damselfish (Dascyllus trimaculatus) species-complex. Proc Biol Sci. 2002;269:599-605.

8. Bowen BW Muss A, Rocha LA Grant WS. Shallow mtDNA coalescence in Atlantic pygmy angelfish (genus Centropyge) indicates a recent invasion from the Indian Ocean. J Hered. 2006:97:1-12.

9. Wainwright PC, Bellwood DR. Ecomorphology of feeding in coral reef fishes. In: Sale PF, editor. Coral reef fishes: dynamics and diversity in a complex ecosystem. San Diego: Academic Press; 2002. p. 33-56.

10. Eschmeyer WN, Fricke R, van der Laan R. Catalog of fishes: genera, species, references. 2016. http://researcharchive.calacademy.org/research/ ichthyology/catalog/fishcatmain.asp. Accessed 08 Jan 2016.

11. Greenfield DW, Woods LP. Eupomacentrus diencaeus Jordan and Rutter, valid species of damselfish from the western tropical Atlantic. Fieldiana Zool. 1974:65:9-20.

12. Allen GR. Damselfishes of the world. Melle: Mergus Publishers; 1991

13. Novelli R, Nunan GW, Lima NRW. A new species of Damselfish genus Stegastes Jenyns, 1842 (Teleostei: Pomacentridae) from the coast of Brazil. Bol Museu Nac. 2000:413:1-12.

14. Souza AT, Ilarri MI, Medeiros PR, Sampaio CLS, Floeter SR. Unusual colour patterns of territorial damselfishes (Pomacentridae: Stegastes) in the Southwestern Atlantic. Mar Biodivers Rec. 2011:4:1-5.

15. Araújo ME, Cunha FEA, Carvalho RAA, Freitas JEP, Nottingham MC, Barros BMN. Ictiofauna marinha do estado do Ceará, Brasil: II Elasmobranchii e Actinopterygii de arrecifes de arenito da região entre marés. Arq Cienc Mar. 2000:33:133-8.

16. Gasparini JL, Floeter SR. The shore fishes of Trindade Island, western South Atlantic. J Nat Hist. 2001;35:1639-56.
17. Gasparini JL, Moura RL, Sazima I. Stegastes trindadensis n. sp. (Pisces: Pomacentridae), a new damselfish from Trindade Island, off Brazil. Bol Mus Biol Mello Leitão. 1999;10:3-11.

18. Floeter SR, Krohling W, Gasparini JL, Ferreira CEL, Zalmon I. Reef fish community structure on coastal islands of the southeastern Brazil: the influence of exposure and benthic cover. Environ Biol Fish. 2007;78:147-60.

19. Vaske T, Lessa RP, Nóbrega M, Montealegre-Quijano S, Marcante Santan F, Bezerra JL. A checklist of fishes from Saint Peter and Saint Paul Archipelago, Brazil. J Appl Ichthyol. 2005;21:75-9.

20. Almeida FFM. Arquipélago de Fernando de Noronha - Registro de monte vulcânico do Atlântico Sul. In: Schobbenhaus C, Campos DA, Queiroz ET, Winge M, Berbert-Born MLC, editors. Sítios Geológicos e Paleontológicos do Brasil. 1st ed. Brasília: Comissão Brasileira de Sítios Geológicos e Paleobiológicos; 2002. p. 361-8.

21. Kikuchi RKP. Atol das Rocas, Litoral do Nordeste do Brasil - Único atol do Atlântico Sul Equatorial Ocidental. In: Schobbenhaus C, Campos DA, Queiroz ET, Winge M, Berbert-Born MLC, editors. Sítios Geológicos e Paleontológicos do Brasil. 1st ed. Brasília: Comissão Brasileira de Sítios Geológicos e Paleobiológicos; 2002. p. 379-90.

22. Emery AR. A new species of damselfish (Pisces: Pomacentridae) from the eastern coast of South America. Copeia. 1972. doi:10.2307/1442495.

23. Molina WF. Chromosome changes and stasis in marine fish groups. In: Pisano E, Ozouf-Costaz C, Foresti F, Kapoor BG, editors. Fish cytogenetics. 1st ed. Enfield: Science; 2007. p. 69-110.

24. Dias-Júnior EA, Souza AS, Molina WF. Lack of interpopulation genetic structure in the genus Stegastes (Perciformes) with indication of local introgression. Genet Mol Res. 2007;6:1097-106.

25. Carter JA, Kaufman L. Pomacentridae. In: Carpenter KE, editor. The living marine resources of the Western Central Atlantic, vol. 3. Rome: FAO; 2003. p. 1694-700.

26. Pinheiro HT, Mazzei E, Moura RL, Amado-Filho GM, Carvalho-Filho A, Braga AC, et al. Fish biodiversity of the Vitória-Trindade Seamount Chain, Southwestern Atlantic: an updated database. PLoS ONE. 2015. doi:10.1371/journal.pone.0118180.

27. Lubbock R, Edwards A. The fishes of Saint Paul's Rocks. J Fish Biol. 1981;18:135-57.

28. Souza AT, Ilarri MI, Rosa IL. Habitat use, feeding and territorial behavior of a Brazilian endemic damselfish Stegastes rocasensis (Actinopterygii: Pomacentridae). Environ Biol Fish. 2011;91:133-44.

29. Souza AT, Ilarri MI. Behavioral changes of a Brazilian endemic damselfish Stegastes rocasensis when guarding egg clutches. Environ Biol Fish. 2014;97:1295-303.

30. Molina WF, Galetti PM Jr. Multiple pericentric inversions and chromosomal divergence in the reef fishes Stegastes (Perciformes, Pomacentridae). Genet Mol Biol. 2004;27:443-8.

31. Dias-Júnior EA, Molina WF. Análise de similaridade genética entre espécies insulares endêmicas e costeiras do gênero Stegastes (Perciformes) através de marcadores moleculares RAPD. Publica. 2008;4:37-46.

32. Morrison DF. Multivariate statistical methods. 2nd ed. Singapore: McGraw Hill; 1976.

33. MacLeod N. Shear. In: Rohlf FL, Bookstein FL, editors. Proceedings of Michigan morphometrics workshop. Michigan: University of Michigan; 1990.

34. Rohlf FJ. tpsDig 2.16, digitize landmarks and outlines. New York: State University of New York; 2010.

35. Rohlf FJ. tpsUtil 1.46. New York: State University of New York; 2010

36. Dryden IL, Mardia KV. Statistical shape analysis. New York: Wiley; 1998.

37. Sambrook J, Fritsch EF, Maniatis T. Molecular cloning: a laboratory manual. New York: Could Spring Harbor Laboratory Press; 1989.

38. Hall TA. BioEdit: a user-friendly biological sequence alignment editor and analysis program for Windows 95/98/NT. In: Nucleic acid symposium series no. 41; 1999. p. 95-8.

39. Edgar RC. Muscle: multiple sequence alignment with high accuracy and high throughput. Nucleic Acids Res. 2004;32:1792-7.

40. Tamura K, Stecher G, Peterson D, Filipski A, Kumar S. Mega 6: molecular evolutionary genetics analysis. Mol Biol Evol. 2013;30:2725-9.

41. Darriba D, Taboada GL, Doallo R, Posada D. jModelTest2: more models, new heuristics and parallel computing. Nat Methods. 2012. doi:10.1038/ nmeth.2109.

42. Kaufman L, Liem KF. Fishes of the suborder Labroidei (Pisces: Perciformes): phylogeny, ecology, and evolutionary significance. Breviora. 1982;472:1-19. 
43. Librado P, Rozas J. DnaSP 5: a software for comprehensive analysis of DNA polymorphism data. Bioinformatics. 2009;25:1451-2.

44. Rivas LR. The fishes of the genus Pomacentrus in Florida and the western Bahamas. Q J Fla Acad Sci. 1960;23:130-62.

45. Victor BC. Hypoplectrus floridae n. sp. and Hypoplectrus ecosur n. sp., two new Barred Hamlets from the Gulf of Mexico (Pisces: Serranidae): more than 3\% different in COI mtDNA sequence from the Caribbean Hypoplectrus species flock. J Ocean Sci Found. 2012;5:1-19.

46. Lima-Filho PA, Molina WF, Cioffi MB, Bertollo LAC. Chromosomal and morphological divergences in Atlantic populations of the frillin goby Bathygobius soporator (Gobiidae, Perciformes). J Exp Mar Biol Ecol. 2012;434:63-70

47. César FB. Idade, crescimento e distribuição de Stegastes rocasensis (Emery, 1972), no Atol das Rocas, e Stegastes sanctipauli (Lubbock \& Edwards, 1981), no Arquipélago de São Pedro e São Paulo. Trop Oceanogr. 2010;38:234.

48. Palacios-Salgado DS, Rojas-Herrera A. Partial xanthism in a specimen of Acapulco major, Stegastes acapulcoensis (Teleostei: Pomacentridae), from the Tropical Eastern Pacific. Panam J Aquat Sci. 2012;7:175-7.

49. Araújo ME, Maranhão HA, Véras DP, Hazin F. Unusual coloration pattern in juveniles of Stegastes fuscus (Actinopterygii: Pomacentridae). Zootaxa. 2009:2081:67-8.

50. Vella A, Agius Darmanin S, Vella N. Morphological and genetic barcoding study confirming the first Stegastes variabilis (Castelnau, 1855) report in the Mediterranean Sea. Mediterr Mar Sci. 1855. doi:10.12681/mms.1391.

51. Cunha IMC, Souza AS, Dias Junior EA, Amorim KDJ, Soares RX, Costa GWWF, Machado EG, Galetti PM Jr, Molina WF. Genetic multipartitions based on D-loop sequences and chromosomal patterns in Brown Chromis, (Pomacentridae), in the Western Atlantic. Biomed Res Int. 2014;2014:254698.

52. Menezes NA, Figueiredo JL. Manual de peixes marinhos do sudeste do Brasil. V. Teleostei (4). São Paulo: Museu de Zoologia da Universidade de São Paulo; 1985

53. Mérona B, Mol J, Vigouroux R, Chaves PT. Phenotypic plasticity in fish life-history traits in two neotropical reservoirs: Petit-Saut Reservoir in French Guiana and Brokopondo Reservoir in Suriname. Neotrop Ichthyol. 2009:7:683-92.

54. Rocha LA. Patterns of distribution and processes of speciation in Brazilian reef fishes. J Biogeogr. 2003;30:1161-71.
55. Mittelbach GG, Osenberg CW, Wainwright PC. Variation in resource abundance affects diet and feeding morphology in the pumpkinseed sunfish (Lepomis gibbosus). Oecologia. 1992;90:8-13.

56. Walker JA. Ecological morphology of lacustrine threespine stickleback Gasterosteus aculeatus (Gasterosteidae) body shape. Biol J Linn Soc. 1997;61:3-50.

57. Wainwright PC, Collar DC, Alfaro ME. Integrated diversification of locomotion and feeding in labrid fishes. Biol Lett. 2007;4:84-6.

58. Werner EE. Species packing and niche complementarity in three sunfishes. Am Nat. 1977;111:553-79.

59. Webb PW. Effect of body form and response threshold on the vulnerability of four species of teleost prey attacked by largemouth bass (Micropterus salmoides). Can J Fish Aquat Sci. 1986;43:763-71.

60. Piorski NM, Alves JR, Machado MRD, Correia MMV. Alimentação e ecomorfologia de duas espécies de piranhas (Characiformes: Characidae) do lago de Viana, Maranhão, Brasil. Acta Amaz. 2005;35:63-70.

61. Molina WF, Shibatta OA, Galetti PM Jr. Multivariate morphological analyses in continental and island populations of Abudefduf saxatilis (Linnaeus) (Pomacentridae, Perciformes) of Western Atlantic. Panam J Aquat Sci. 2006;1:49-56.

62. Ward RD. DNA barcode divergence among species and genera of birds and fishes. Mol Ecol Resour. 2009:9:1077-85.

63. Feitoza BM, Rocha LA, Luiz-Júnior OJ, Floeter SR, Gasparini JL. Reef fishes of St. Paul's Rocks: new records and notes on biology and zoogeography. Aqua. 2003;7:61-82

64. Dobzhansky T, Spassky B. Drosophila paulistorum, a cluster of species in statu nascendi. Proc Natl Acad Sci USA. 1959:45:419-28.

65. Palumbi SR, Martin AP, Romano S, Mcmillan NWO, Stice L, Grabowski G. The simple fool's guide to PCR. Honolulu: University of Hawaii; 1991.

66. Ward RD, Zemlak TS, Innes BH, Last PR, Hebert PD. DNA barcoding Australia's fish species. Philos Trans R Soc Lond B Biol Sci. 2005;360:1847-57.

67. Jiménez S, Schönhuth S, Lozano IJ, González JA, Sevilla RG, Diez A, Bautista JM. Morphological, ecological and molecular analyses separate Muraena augusti from Muraena helena as a valid species. Copeia. 2007:1:101-13.

68. Reece JS, Bowen BW, Joshi K, Goz V, Larson A. Phylogeography of two moray eels indicates high dispersal throughout the Indo-Pacific. J Hered. 2010;102:1-12.

\section{Submit your next manuscript to BioMed Central and we will help you at every step:}

- We accept pre-submission inquiries

- Our selector tool helps you to find the most relevant journal

- We provide round the clock customer support

- Convenient online submission

- Thorough peer review

- Inclusion in PubMed and all major indexing services

- Maximum visibility for your research

Submit your manuscript at www.biomedcentral.com/submit
O Biomed Central 